\title{
Sublittoral meiobenthic assemblages from disturbed and non-disturbed sediments in the Balearies*
}

\author{
S. DEUDERO ${ }^{1}$ and M. VINCX
} University of Gent, Department of Morphology, Systematics and Ecology, Marine Biology Section, B-9000 Gent, Belgium.
${ }^{1}$ Present address: Department of Marine Sciences and Coastal Management. University of Newcastle. Newcastle upon Tyne NE1 7RU. E-mail: Salud.Deudero@ncl.ac.uk

\begin{abstract}
SUMMARY: Qualitative and quantitative differences in species composition of meiobenthic communities illustrate the differences among various taxonomic assemblages in the Balearic Islands (Western Mediterranean) analysed by means of multivariate analysis. Average densities ranged between 1000 and 4000 ind $10 \mathrm{~cm}^{-2}$, and are in the same range as previously reported from other shallow Mediterranean areas. The dominant meiofaunal taxa were Nematoda (range 40 to $75 \%$ ), Turbellaria (5-47\%) and Copepoda (2-14\%), while other meiofaunal groups (Tardigrada and Rotifera) were only represented by approximately $5 \%$ of the total abundance. The dominant nematode families were Desmodoridae, Chromadoridae and Xyalidae. The meiofaunal communities showed little variation among locations. Moreover, small-scale heterogeneity does not seem to affect nematode distribution as shown by the high similarity between replicates in the multivariate analysis.
\end{abstract}

Key words: meiofauna, community structure, nematode composition, Western Mediterranean.

\section{INTRODUCTION}

The establishment of the first Spanish Marine National Park of Cabrera (Balearic Islands) in 1991 provided a good scenario for base-line studies of indicator species, especially regarding benthic organisms. Various studies have investigated meiofaunal community structure in relation to different types of pollution (Palacín et al., 1992; Smol et al., 1994; Danovaro et al., 1995b; Papadopoulou et al., 1998; Schratzberger and Warwick, 1998; Lardicci et al., 1999). Nematodes are more tolerant of detrimental conditions than most other groups and have been found to survive as the only group of higher animals in very polluted waters. Therefore, we

\footnotetext{
*Received February 5, 1998. Accepted March 16, 2000.
}

selected this taxocene to study the level of anthropogenic influence by comparing stations from a pristine protected area (Cabrera) versus a disturbed location (Mallorca). Nevertheless, many natural environmental factors such as water depth and sediment granulometry, oxygenation of the sediment, and biotic interactions also modify community structure, therefore it is not easy to separate natural from anthropogenic effects. Measurement of the community structure usually has limitations in discriminating between the effects of chemical stress, natural physical disturbances, pollution and biological disturbance (Gray, 1971).

The present study is concerned with meiofauna spatial distribution and population density focusing particularly on the genus composition of the nematode fauna in subtidal shallow sediments. Secondary 
objectives are 1) to define the nematode community in terms of genus composition; and 2) to describe the major meiobenthic assemblages according to habitat and sediment structure. Various studies have previously been carried out in the Western Mediterranean (Bougis, 1946; Soyer, 1971; Boucher, 1972, 1980; de Bovée, 1987, 1988; Soyer et al., 1987; Palacín et al., 1991, 1992). Moreover, most of the more recent Mediterranean subtidal studies on meiobenthic communities have been centred in deep-sea transects (de Bovée et al., 1990; Soetaert et al., 1991; Danovaro et al., 1995a; Schewe and Soltwedel, 1999; Soetaert et al., 1991, 1995; Soetaert and Heip, 1995) or in estuaries (Danovaro et al., 1995a; Guidiguilvard and Buscail, 1995; Albertelli et al., 1999). In contrast, our study is confined to particularly shallow depths (between 2 and $4 \mathrm{~m})$ and represents the first data available from the Balearic Islands reporting on composition and density range of the nematocenosis and allowing a comparison with other Mediterranean shallow areas.

\section{MATERIAL AND METHODS}

\section{Study area}

Four stations were studied in the National Park of Cabrera (Cabrera, Western Mediterranean), where human activities are restricted. In addition, three stations were chosen around the main island of the Balearics, Mallorca, in order to recognise the geographical disparities between the meiobenthic communities (Fig. 1). Two stations were located in the Port of Cabrera (st.1 and st.2), a relatively semienclosed bay that serves as an anchoring site. Two more stations (st. 3 and st.4) were positioned in Ganduf, an adjacent bay where access is forbidden, both for humans and boats. The Mallorca stations (st.5 and st.6) were situated in the southeast of the island in an area without human settlements, whereas st.7 was under the influence of an area with mass tourism pressure.

Sediment parameters (median grain size, percentage silt, percentage sand, amount of gravel), redox-potential discontinuity layer (RPD), depth, temperature of sediment and water were considered as environmental factors. The sandy bottom was partly covered by Posidonia oceanica seagrass. Depth and sediment temperature were the same for all the stations, $2-4$ metres and $25^{\circ} \mathrm{C}$ respectively (Table 1), whereas the surface water temperature

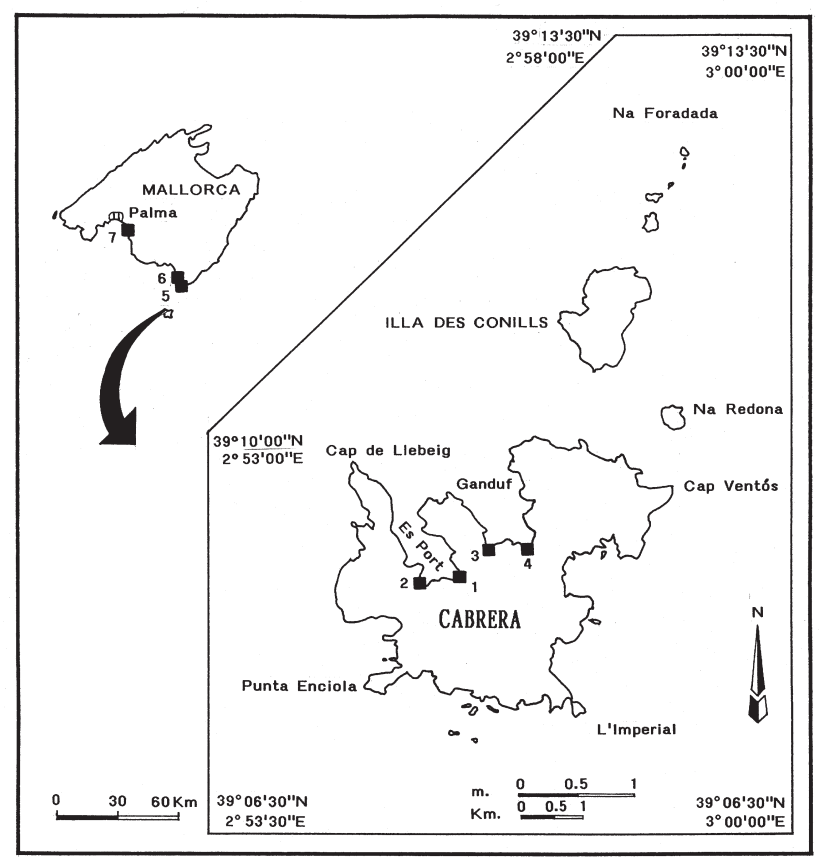

FIG. 1. - Location of the study area.

varied from $14.6^{\circ} \mathrm{C}$ (in February) to $27.5^{\circ} \mathrm{C}$ (in August). The redox-potential discontinuity layer (RPD) was visually determined in the sample core. According to the substratum, two types of communities could be distinguished: 1) soft substratum communities dominated by Posidonia oceanica seagrass meadows (stations 1 to 6) and 2) sandy surfaces (station 7).

\section{Sampling}

Sediment samples were collected by SCUBA diving in September 1992 at the 7 stations. Five plastic cores of $10 \mathrm{~cm}^{2}$ surface area were placed into a quadrate with $14 \mathrm{~cm}$ side. Water and sediment temperatures were recorded in situ by means of a mercury thermometer. Size distribution of the particles was measured by means of a Coulter LS 100 Particle Size Analyser. On deck, the core samples were preserved in a warm $\left(60^{\circ} \mathrm{C}\right) 4 \%$ buffered seawaterformaldehyde solution to prevent curling of the animals.

Extraction of the fauna from the sediment was achieved using the LUDOX centrifugation flotation technique described by McIntyre and Warwick (1984) and Heip et al. (1985). Organisms were retained on a $38 \mu \mathrm{m}$ sieve. Samples were preserved with $8 \%$ formaldehyde solution and stained with Rose Bengal. Higher taxa were counted and sorted under a stereoscopic microscope, and 200 nema- 
TABLE 1. - Sediment granulometry and environmental variables at the 7 stations of the Balearic Islands.

\begin{tabular}{|c|c|c|c|c|c|c|c|}
\hline & $\begin{array}{c}\text { St. } 1 \\
\text { Port Cabrera }\end{array}$ & $\begin{array}{c}\text { St. } 2 \\
\text { Port Cabrera }\end{array}$ & $\begin{array}{c}\text { St. } 3 \\
\text { Ganduf, Cabrera }\end{array}$ & $\begin{array}{c}\text { St. } 4 \\
\text { Ganduf, Cabrera }\end{array}$ & $\begin{array}{c}\text { St. } 5 \\
\text { Mallorca }\end{array}$ & $\begin{array}{c}\text { St. } 6 \\
\text { Mallorca }\end{array}$ & $\begin{array}{c}\text { St. } 7 \\
\text { Arenal, Mallorca }\end{array}$ \\
\hline Depth (m) & 1.9 & 2.25 & 2 & 3.7 & 2 & 2.5 & 2.25 \\
\hline RPD layer $(\mathrm{cm})$ & below $10 \mathrm{~cm}$ & below $10 \mathrm{~cm}$ & below $10 \mathrm{~cm}$ & below $10 \mathrm{~cm}$ & below $10 \mathrm{~cm}$ & 2.6 & $3-3.5$ \\
\hline Habitat & $\begin{array}{l}\text { Seagrass } \\
\text { spots }\end{array}$ & $\begin{array}{l}\text { Seagrass } \\
\text { spots } \\
\text { seagrass beds }\end{array}$ & $\begin{array}{l}\text { Small sand spots } \\
\text { among } \\
\text { seagrass beds } \\
\text { of Posidonia }\end{array}$ & $\begin{array}{l}\text { Small sand } \\
\text { spots among } \\
\text { and patches } \\
\text { of Posidonia }\end{array}$ & $\begin{array}{l}\text { Flat rocky substrate } \\
\text { covered by sand } \\
\text { sand and patches }\end{array}$ & $\begin{array}{l}\text { Flat rocky substrate } \\
\text { covered by }\end{array}$ & Sand \\
\hline median grain size $(\mathrm{mm})$ & 0.47 & 0.38 & 0.15 & 0.17 & 0.52 & 0.30 & 0.13 \\
\hline$\%$ silt & 2.04 & 7.5 & 22.1 & 9.5 & 2.8 & 4.2 & 0.1 \\
\hline$\%$ sand & 97.96 & 92.51 & 77.87 & 90.52 & 97.23 & 95.8 & 99.89 \\
\hline gravel* & 48 & 52.97 & 19.22 & 13.24 & 2.6 & 0.25 & 1.13 \\
\hline
\end{tabular}

* weight $(\mathrm{g})$ of the gravel in a core of $10 \mathrm{~cm}$ depth

$\%$ silt $(>63 \mu \mathrm{m}), \%$ sand $(63 \mu \mathrm{m}-1 \mathrm{~mm})$ calculated on a $200 \mathrm{ml} / 1$ sediment aliquot at each station with a Coulter LS100 Fluid Model.

todes were picked out in each replicate and mounted on slides for further identification at the genus level. The pictorial key of Platt and Warwick (1983a, 1983b) was used for classification.

\section{Statistics}

Multivariate analysis was applied to describe the structure of the meiobenthic communities in relation to environmental factors. A classification clustering based on the Bray-Curtis similarity index was applied to the nematode abundance. A TWINSPAN (TWo-way INdicator SPecies Analysis) classification technique was calculated for twenty-three replicates for all the nematode species on the basis of their relative abundance.

A Kruskal-Wallis analysis of variance by ranks was performed on the densities (5 replicates/station) for the twenty meiofaunal taxa in order to test differences between the seven stations.

\section{RESULTS}

\section{Sediment}

At the majority of the stations the sediment was classified as fine to medium sand (Wentworth Scale). Median grain size was maximum at station 5 $(0.516 \mathrm{~mm})$ and minimum at station $7(0.125 \mathrm{~mm})$ (Table 1). Station 3 showed the highest value of the silt fraction $(<63 \mu \mathrm{m})$ with $22.1 \%$, whereas stations 2 and 4 had approximately the same amount, followed by station 6 . Stations 1 and 5 had similar silt values of 2 and $2.8 \%$ respectively. The lowest silt value was found at station $7(0.1 \%)$. Stations 1 and 2 showed the highest weight of gravel associated with the dominance of Posidonia oceanica beds covering most of the surface. Regarding the redoxpotential discontinuity (RPD) level, stations 1 to 5 presented a deep RPD layer as expected in sandy sediments; however, at stations 6 and 7 this level was more superficial (Table 1).

\section{Meiofauna}

The average densities of the meiobenthos at the seven stations varied from 1075 individuals $10 \mathrm{~cm}^{-2}$ to 4137 individuals $10 \mathrm{~cm}^{-2}$ (Table 2). Kruskal-Wallis analysis of variance showed significant differences between the seven stations for kinorhynchs, polychaetes, oligochaetes, turbellarians, gastrotrichans, cnidarians, nematodes, copepods and tardigrads $(\mathrm{p}<0.05)$. The dominant meiofaunal group was the Nematoda, with a mean density ranging from 424 to 2779 individuals $10 \mathrm{~cm}^{-2}$, which represented $39-78 \%$ of the overall total. The lowest densities were found at stations 3 and 5 while the highest corresponded to stations 4 and 7 . The second dominant taxon was Turbellaria, with 170-1100 individuals $10 \mathrm{~cm}^{-2}(5-47 \%$ of the total) and a particularly high density at station 6. Nauplii ranged from $2.5 \%$ to $20 \%$. Copepoda densities followed in dominance $(2-14 \%)$ together with Polychaeta (4$7 \%)$, Rotifera (1-5\%), and Tardigrada (4\%). Copepoda were present mainly at stations 1 and 2, with very low values at station 3 . Other meiofaunal groups showed lower numbers of individuals, such as Gastrotricha (0.05-3.25\%), Kinorhyncha (1-2\%), Oligochaeta $(0.07-1.11 \%)$ and Ostracoda (0.07$1.7 \%)$. The lowest values corresponded to Amphipoda, Cnidaria, Cumacea, Halacarida, Isopoda, Nemertina, Priapulida, and Tunicata, with only a few individuals in the samples. 
TABLE 2. - Mean meiofaunal densities (individuals $10 \mathrm{~cm}^{-2}$ ) and standar error (S.E.) for 5 replicates/station.

\begin{tabular}{|c|c|c|c|c|c|c|c|c|c|c|c|c|c|c|}
\hline & $\begin{array}{l}\text { Stat } 1 \\
\text { mean }\end{array}$ & S.E. & $\begin{array}{l}\text { Stat } 2 \\
\text { mean }\end{array}$ & S.E. & $\begin{array}{l}\text { Stat } 3 \\
\text { mean }\end{array}$ & S.E. & $\begin{array}{r}\text { Stat } 4 \\
\text { mean }\end{array}$ & S.E. & $\begin{array}{r}\text { Stat } 5 \\
\text { mean }\end{array}$ & S.E. & $\begin{array}{l}\text { Stat } 6 \\
\text { mean }\end{array}$ & S.E. & $\begin{array}{l}\text { Stat } 7 \\
\text { mean }\end{array}$ & S.E. \\
\hline Amphipoda & 0.0 & 0.0 & 0.0 & 0.0 & 0.4 & 0.9 & 0.0 & 0.0 & 0.0 & 0.0 & 0.0 & 0.0 & 0.0 & 0.0 \\
\hline Cnidaria & 0.0 & 0.0 & 4.8 & 3.9 & 0.0 & 0.0 & 0.0 & 0.0 & 0.0 & 0.0 & 0.0 & 0.0 & 0.0 & 0.0 \\
\hline Copepoda & 357.0 & 139.5 & 453.6 & 133.6 & 20.0 & 14.6 & 196.8 & 71.7 & 141.2 & 30.2 & 76.0 & 32.0 & 218.4 & 181.3 \\
\hline Cumacea & 0.0 & 0.0 & 0.0 & 0.0 & 0.0 & 0.0 & 0.0 & 0.0 & 0.0 & 0.0 & 0.8 & 1.6 & 0.0 & 0.0 \\
\hline Gastrotricha & 134.6 & 28.0 & 90.4 & 53.4 & 15.3 & 16.3 & 1.6 & 2.0 & 0.0 & 0.0 & 12.8 & 5.8 & 4.8 & 6.4 \\
\hline Halacarida & 3.2 & 5.1 & 0.8 & 1.6 & 0.2 & 0.4 & 0.8 & 1.7 & 0.0 & 0.0 & 0.0 & 0.0 & 0.0 & 0.0 \\
\hline Insecta & 0.2 & 0.4 & 0.0 & 0.0 & 0.0 & 0.0 & 0.0 & 0.0 & 0.0 & 0.0 & 0.0 & 0.0 & 0.0 & 0.0 \\
\hline Isopoda & 0.0 & 0.0 & 0.0 & 0.0 & 0.0 & 0.0 & 0.0 & 0.0 & 0.8 & 1.6 & 0.0 & 0.0 & 0.0 & 0.0 \\
\hline Kinorhyncha & 39.8 & 33.1 & 59.2 & 32.5 & 0.0 & 1.6 & 0.0 & 0.0 & 0.0 & 0.0 & 0.0 & 0.0 & 0.0 & 0.0 \\
\hline Nauplii & 265.2 & 155.6 & 372.0 & 95.0 & 26.7 & 18.4 & 178.4 & 43.6 & 241.2 & 85.6 & 113.6 & 30.6 & 183.2 & 134.8 \\
\hline Nematoda & 1850.2 & 601.0 & 1672.0 & 163.0 & 423.8 & 188.7 & 2517.6 & 643.0 & 558.8 & 207.2 & 952.8 & 197.5 & 2778.4 & 1175.3 \\
\hline Nemertina & 0.0 & 0.0 & 0.0 & 0.0 & 0.0 & 0.0 & 0.0 & 0.0 & 0.0 & 0.0 & 7.2 & 6.4 & 2.4 & 3.2 \\
\hline Oligochaeta & 26.4 & 19.9 & 20.0 & 10.0 & 11.9 & 6.9 & 3.2 & 3.9 & 0.8 & 1.6 & 0.0 & 0.0 & 0.0 & 0.0 \\
\hline Ostracoda & 70.2 & 47.1 & 55.2 & 24.9 & 4.9 & 5.4 & 19.2 & 10.3 & 16.4 & 13.1 & 5.6 & 4.2 & 2.4 & 2.0 \\
\hline Polychaeta & 157.8 & 101.5 & 225.6 & 62.1 & 17.4 & 13.4 & 8.8 & 7.8 & 8.8 & 4.6 & 2.4 & 3.2 & 1.6 & 2.0 \\
\hline Priapulida & 0.8 & 1.6 & 0.8 & 1.6 & 0.0 & 0.0 & 0.0 & 0.0 & 0.0 & 0.0 & 0.0 & 0.0 & 0.0 & 0.0 \\
\hline Rotifera & 30.4 & 22.8 & 64.0 & 18.0 & 46.2 & 13.8 & 72.0 & 31.9 & 64.4 & 18.5 & 64.0 & 20.2 & 30.4 & 18.6 \\
\hline Tardigrada & 80.0 & 67.1 & 125.6 & 72.1 & 0.3 & 0.5 & 30.4 & 10.4 & 18.8 & 15.8 & 20.8 & 9.4 & 11.2 & 8.2 \\
\hline Tunicata & 0.0 & 0.0 & 0.0 & 0.0 & 0.0 & 0.0 & 0.0 & 0.0 & 0.0 & 0.0 & 0.0 & 0.0 & 0.8 & 1.6 \\
\hline Turbellaria & 223.0 & 43.6 & 178.4 & 14.2 & 507.5 & 112.2 & 348.0 & 67.6 & 170.4 & 22.8 & 1100.8 & 234.2 & 332.8 & 132.5 \\
\hline unknown & 1.4 & 1.7 & 2.4 & 3.2 & 0.0 & 0.0 & 0.0 & 0.0 & 0.0 & 0.0 & 0.0 & 0.0 & 1.6 & 3.2 \\
\hline TOTAL & 4137 & 1112.0 & 3325 & 525.3 & 1075 & 362.5 & 3377 & 786.3 & 1222 & 329.3 & 2357 & 382.9 & 3568 & 1476.1 \\
\hline
\end{tabular}

\section{Nematode communities}

A total of 128 genera were identified from 3829 nematodes collected at the seven stations distributed among twenty-three replicates. Spirinia was the most abundant genus (7.9\%) followed by Theristus (7\%), Hypodontolaimus (6.7\%), Paracomesoma (4.3\%) and Daptonema (4.2\%). These five genera comprised approximately $30 \%$ of the total nematode numbers, and together with the 31 other genera listed in Table 3, accounted for $90 \%$ of the total abundance. An unidentified genus, listed as Genus A, was placed into the non-selective deposit feeders (Type 1B trophic group) based on the structure of the buccal cavity.

Figure 2 shows the TWINSPAN classification of 128 nematode genera belonging to 28 families. A resemblance was found between the following stations: Port de Cabrera (TWIN I, st.1, st.2; indicator species: Spiliphera, Pomponema, Latronema and Monoposthia); the Mallorca stations (TWIN II, st.5, st.6, st.7; indicator species: Cobbia, Odontophora, Paramesonchium, Aponema and Aegialoalaimus); and Ganduf bay (TWIN III, st.3, st.4; indicator species: Metalinhomoeus, Synonchiella, Genus A and Paracomesoma).

The results of the cluster analysis identified the assemblages of stations that shared common environmental features (Gray and Pearson, 1982). Cluster analysis on nematodes revealed the same pattern as the TWINSPAN technique. On the basis of this comparison, the nematodes at the seven stations could be arranged into three faunal units. Figure 3 shows that the replicates at each station were faunistically very similar. The first group was comprised of the organisms found at the very fine sand to medium sand stations 5, 6 and 7 (Mallorca sites). Station 5 was characterised by the dominance of two families, Xyalidae representing $30 \%$ of the total nematode taxocenosis, and Desmodoridae with the same percentage. Chromadoridae followed in abundance with 7\%. An even higher dominance of Desmodoridae $(54 \%)$ was present at station 6 , followed by approximately $14 \%$ of Leptolaimidae and $7 \%$ of Xyalidae. At station 7, Xyalidae were dominant (25\%), together with Selachinematidae (14\%). Therefore, the nematode populations at these three stations showed a higher degree of faunal dominance by either one or a few species. At station 5 the dominant genera were Theristus, Spirinia, Onyx, Prochromadorella and Eubostrichus. Station 6 was characterised by Spirinia, Leptolaimus, Metachromadora, Chromaspirina and Daptonema. At station 7: Cobbia, Richtersia, Nannolaimoides, Spirinia, Comesa, Paramesonchium, Odontophora and Daptonema.

The medium sand stations 1 and 2 (Port De Cabrera) comprised the second cluster. Members of the Chromadoridae family accounted for $24.5 \%$ at station 1, whereas station 2 exhibited $14 \%$ of Tre- 
TABLE 3. - The 45 most dominant nematode genera accounting for $90 \%$ of the total (percentage average for all replicates and standard error (S.E.).

\begin{tabular}{|c|c|c|c|c|c|c|c|c|c|c|c|c|c|c|c|}
\hline Genus & St1 & S.E. & St2 & S.E. & St3 & S.E. & $\mathrm{St} 4$ & S.E. & St5 & S.E. & St6 & S.E. & $\mathrm{St} 7$ & S.E. & average $\%$ \\
\hline Spirinia & 0.00 & & 0.30 & 0.50 & 1.95 & 2.57 & 0.00 & & 13.87 & 4.50 & 31.02 & 3.00 & 8.20 & 5.16 & 7.91 \\
\hline Theristus & 0.35 & 0.80 & 0.30 & 0.50 & 4.39 & 3.38 & 11.11 & 0.50 & 29.63 & 10.50 & 2.35 & 1.00 & 0.86 & 0.80 & 7.00 \\
\hline Hypodontolaimus & 1.07 & 1.16 & 2.03 & 0.50 & 0.00 & & 42.19 & 4.00 & 0.00 & & 2.06 & 1.50 & 0.00 & & 6.76 \\
\hline Paracomesoma & 0.00 & & 0.00 & & 28.42 & 13.44 & 2.28 & 0.00 & 0.00 & & 0.00 & & 0.00 & & 4.39 \\
\hline Daptonema & 9.97 & 3.54 & 5.58 & 1.50 & 1.40 & 1.49 & 1.71 & 1.00 & 0.00 & & 6.68 & 0.50 & 4.60 & 0.40 & 4.28 \\
\hline Pomponema & 13.65 & 9.65 & 6.27 & 7.00 & 0.25 & 0.48 & 0.00 & & 0.28 & 0.50 & 0.58 & 0.00 & 0.96 & 1.85 & 3.14 \\
\hline genus $\mathrm{A}$ & 0.00 & & 0.00 & & 19.87 & 13.16 & 2.00 & 0.50 & 0.00 & & 0.00 & & 0.00 & & 3.12 \\
\hline Cobbia & 0.00 & & 0.61 & 1.00 & 0.00 & & 0.00 & & 0.00 & & 0.00 & & 20.12 & 4.14 & 2.96 \\
\hline Odontophora & 0.00 & & 0.00 & & 0.33 & 0.80 & 9.96 & 2.50 & 2.06 & 1.00 & 3.19 & 3.50 & 4.61 & 3.00 & 2.88 \\
\hline Nannolaimoides & 0.49 & 1.16 & 2.62 & 0.50 & 4.35 & 4.45 & 1.99 & 1.50 & 0.00 & & 0.29 & 0.50 & 9.03 & 4.40 & 2.68 \\
\hline Prochromadorella & 8.55 & 6.71 & 0.91 & 1.50 & 0.60 & 0.63 & 0.00 & & 7.09 & 9.00 & 0.30 & 0.50 & 0.60 & 1.09 & 2.58 \\
\hline Richtersia & 1.33 & 2.03 & 2.10 & 2.50 & 0.00 & & 0.00 & & 0.00 & & 0.30 & 0.50 & 14.28 & 13.60 & 2.57 \\
\hline Leptolaimus & 0.24 & 0.48 & 0.28 & 0.50 & 0.00 & & 2.58 & 2.50 & 0.00 & & 13.75 & 1.50 & 0.26 & 0.48 & 2.44 \\
\hline Metachromadora & 0.93 & 1.35 & 0.61 & 1.00 & 0.00 & & 0.29 & 0.50 & 1.97 & 0.00 & 11.42 & 2.50 & 0.97 & 1.49 & 2.31 \\
\hline Microlaimus & 10.02 & 13.13 & 0.61 & 1.00 & 0.57 & 2.00 & 0.56 & 1.00 & 0.37 & 0.50 & 3.53 & 3.00 & 0.27 & 0.80 & 2.28 \\
\hline Desmodora & 1.04 & 2.63 & 11.07 & 1.00 & 0.72 & 1.16 & 0.29 & 0.50 & 1.23 & 1.00 & 0.29 & 0.50 & 0.12 & 0.40 & 2.11 \\
\hline Chromaspirina & 0.00 & & 0.00 & & 0.82 & 1.35 & 0.00 & & 1.31 & 0.00 & 11.11 & 0.00 & 0.47 & 0.74 & 1.96 \\
\hline Linhomoeus & 2.01 & 1.95 & 8.41 & 2.50 & 1.53 & 2.93 & 0.00 & & 0.00 & & 0.00 & & 1.12 & 1.83 & 1.87 \\
\hline Paradesmodora & 3.29 & 2.49 & 7.11 & 8.50 & 0.11 & 0.40 & 0.00 & & 1.88 & 1.00 & 0.58 & 1.00 & 0.00 & & 1.85 \\
\hline Nannolaimus & 0.82 & 1.49 & 0.56 & 1.00 & 1.31 & 1.32 & 7.97 & 1.00 & 0.28 & 0.50 & 0.00 & & 1.35 & 1.00 & 1.76 \\
\hline Synonchiella & 0.00 & & 0.30 & 0.50 & 6.55 & 2.78 & 4.53 & 5.00 & 0.00 & & 0.29 & 0.50 & 0.00 & & 1.67 \\
\hline Chromadorita & 4.36 & 3.07 & 5.60 & 2.50 & 0.12 & 0.40 & 0.00 & & 0.00 & & 1.48 & 2.50 & 0.00 & & 1.65 \\
\hline Monoposthia & 5.09 & 3.38 & 2.29 & 2.00 & 0.12 & 0.40 & 0.00 & & 0.94 & 0.50 & 0.87 & 0.50 & 0.98 & 1.20 & 1.47 \\
\hline Latronema & 6.46 & 4.66 & 3.50 & 0.00 & 0.00 & & 0.00 & & 0.00 & & 0.00 & & 0.00 & & 1.42 \\
\hline Onyx & 0.00 & & 0.00 & & 0.00 & & 0.00 & & 9.06 & 9.00 & 0.29 & 0.50 & 0.00 & & 1.34 \\
\hline Metadesmolaimus & 0.00 & & 0.00 & & 0.00 & & 0.56 & 1.00 & 3.66 & 0.50 & 2.62 & 1.50 & 1.80 & 2.96 & 1.24 \\
\hline Spiliphera & 7.53 & 9.04 & 0.91 & 1.50 & 0.00 & & 0.00 & & 0.00 & & 0.00 & & 0.00 & & 1.21 \\
\hline Metalinhomoeus & 0.37 & 0.80 & 0.00 & & 7.29 & 10.74 & 0.57 & 0.00 & 0.00 & & 0.00 & & 0.12 & 0.40 & 1.19 \\
\hline Eubostrichus & 0.12 & 0.40 & 0.28 & 0.75 & 0.00 & & 0.00 & & 6.11 & 1.50 & 1.16 & 2.00 & 0.66 & 1.54 & 1.19 \\
\hline Rhabdocoma & 0.00 & & 7.18 & 8.00 & 0.00 & & 0.00 & & 0.00 & & 0.00 & & 0.00 & & 1.03 \\
\hline Trefusia & 0.00 & & 1.21 & 2.00 & 0.00 & & 5.11 & 3.00 & 0.00 & & 0.00 & & 0.12 & 0.40 & 0.92 \\
\hline Astomonema & 0.95 & 1.01 & 4.95 & 1.00 & 0.00 & & 0.00 & & 0.00 & & 0.00 & & 0.00 & & 0.84 \\
\hline Neochromadora & 3.97 & 6.67 & 1.21 & 2.00 & 0.46 & 0.97 & 0.00 & & 0.00 & & 0.00 & & 0.00 & & 0.81 \\
\hline Leptonemella & 0.12 & & 1.43 & & 0.00 & & 0.00 & & 1.97 & & 0.58 & & 1.24 & & 0.76 \\
\hline Filitonchus & 0.24 & 0.80 & 0.56 & 1.00 & 0.92 & 1.74 & 2.28 & 0.00 & 0.00 & & 0.58 & 1.00 & 0.75 & 0.74 & 0.76 \\
\hline Comesa & 0.00 & & 0.00 & & 0.00 & & 0.00 & & 0.00 & & 0.00 & & 4.95 & 5.76 & 0.71 \\
\hline Perepsilonema & 2.10 & 3.66 & 2.03 & 0.50 & 0.00 & & 0.00 & & 0.37 & 0.50 & 0.30 & 0.50 & 0.13 & 0.40 & 0.71 \\
\hline Oncholaimellus & 0.00 & & 0.00 & & 2.65 & 2.80 & 2.01 & 2.50 & 0.00 & & 0.00 & & 0.00 & & 0.67 \\
\hline Paramesonchium & 0.00 & & 0.00 & & 0.00 & & 0.00 & & 0.00 & & 0.00 & & 4.65 & 3.61 & 0.66 \\
\hline Mesacanthion & 1.41 & 1.35 & 0.00 & & 0.00 & & 0.00 & & 3.18 & 2.50 & 0.00 & & 0.00 & & 0.66 \\
\hline Aponema & 0.00 & & 0.00 & & 0.00 & & 0.00 & & 0.37 & 0.50 & 2.93 & 1.00 & 0.86 & 1.20 & 0.59 \\
\hline Calomicrolaimus & 0.00 & & 0.00 & & 3.40 & 4.53 & 0.00 & & 0.00 & & 0.00 & & 0.38 & 0.80 & 0.54 \\
\hline Axonolaimus & 0.00 & & 0.00 & & 0.00 & & 0.00 & & 3.66 & 0.50 & 0.00 & & 0.00 & & 0.52 \\
\hline Genus B & 0.00 & & 0.00 & & 3.03 & 3.22 & 0.00 & & 0.00 & & 0.00 & & 0.00 & & 0.43 \\
\hline Viscosia & 0.72 & 1.16 & 0.58 & 0.00 & 0.82 & 0.80 & 0.00 & & 0.28 & 0.50 & 0.29 & 0.50 & 0.27 & 0.80 & 0.42 \\
\hline
\end{tabular}

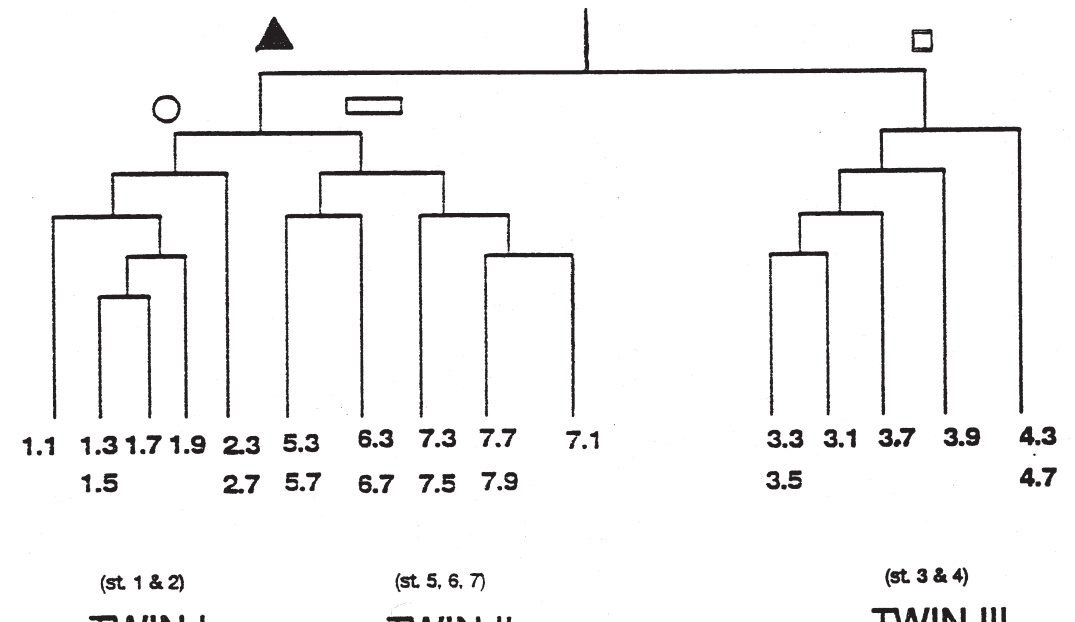

TWIN I

TWIN II

TWIN III

FIG. 2. - Nematodes. TWINSPAN analysis of the samples. 


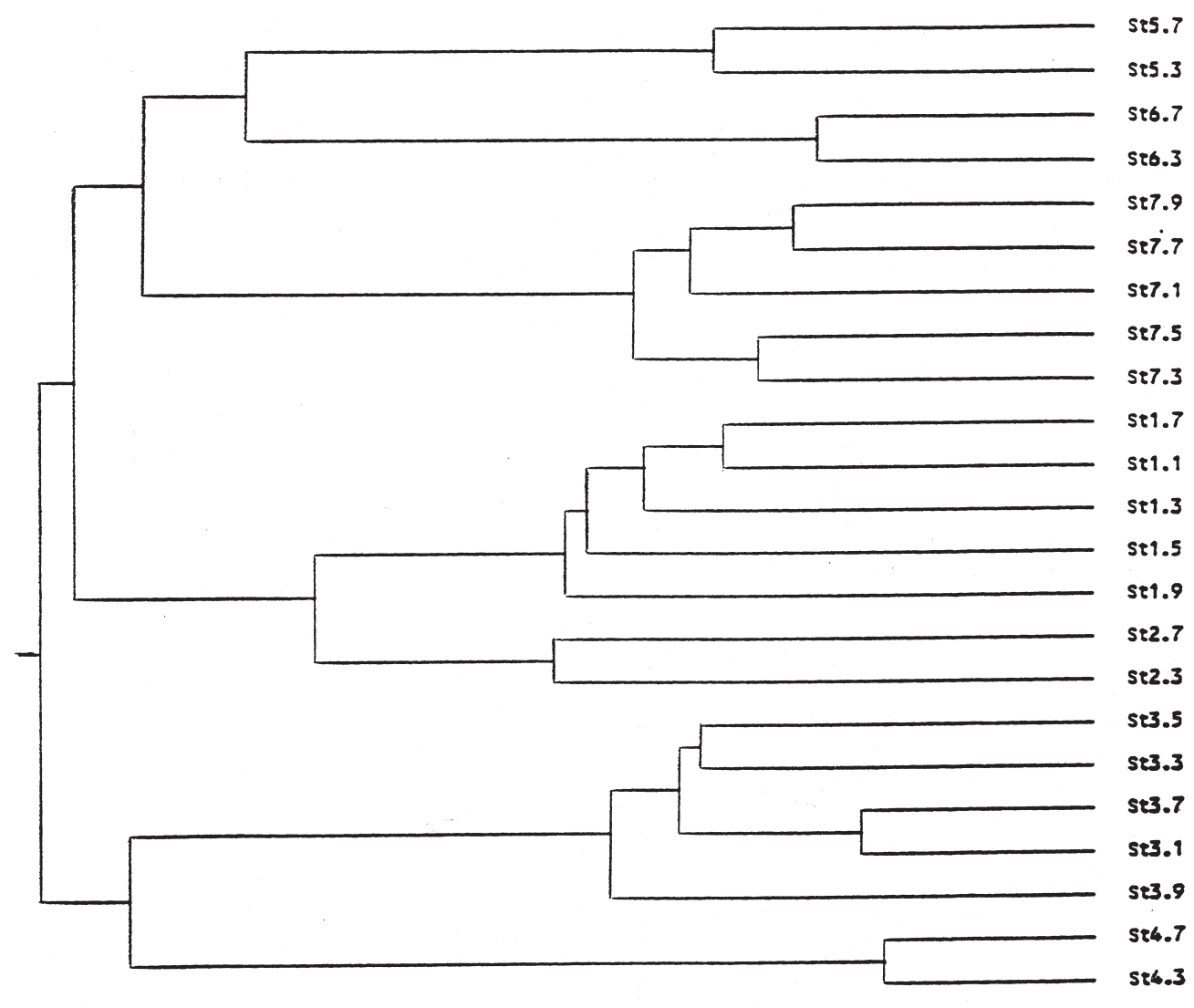

FIG. 3. - Nematodes. Dendrogram for group average sorting of Bray-Curtis similarities.

fusidae, and $11 \%$ of Desmodoridae as dominant families. Station 1 was characterised by Pomponema, Microlaimus, Daptonema, Prochromadorella, Spiliphera, Latronema, Monoposthia, Chromadorita and Neochromadora. Station 2 was characterised by Desmodora, Linhomoeus, Rhabdocoma, Paradesmodora, Pomponema, Chromadorita, Daptone$\mathrm{ma}$ and Astomonema.

The third cluster was characterised by stations 3 and 4 (Cabrera). The main genera at station 3 were Paracomesoma, Genus A, Metalinhomoeus, Synonchiella, Theristus and Nannolaimoides. For station 4 the nematodes were Hypodontolaimus, Theristus, Odontophora, Nannolaimoides, Trefusia and Synonchiella.

\section{DISCUSSION}

Sediment granulometry was not substantially different among the stations, which can be classified as fine to medium sand, except for station 3 that exhibited a high silt amount. The presence of Posidonia oceanica seagrass beds at some of the stations could represent a determining factor in the distribution and composition of the meiobenthic populations. Other authors have reported highest diversities (Villoramoreno et al., 1991; Ndaro and Olafsson, 1999) and abundance (Edgar et al., 1994) of meiobenthic organisms in the presence of seagrass. Our results also showed elevated infaunal abundance in areas of Posidonia seagrass. In contrast, station 7 , the only location covered by nude sand flats exhibited the highest abundance of nematodes $\left(2778 \cdot 10 \mathrm{~cm}^{-2}\right)$ indicating that clear nematode assemblage structures were related to the habitat-type. Moreover, regarding the total meiobenthos significant habitat differences between the seven areas were indicated by the higher meiofaunal abundance at stations 1 and 2 (Port de Cabrera) typified by seagrass beds. These results give support to the assertion on the role of structures in decreasing the risk of predation (Woodin, 1978) or enhancing food availability by flowinduced effects among many other factors. However, infaunal densities can be correlated with the amount of organic material in the sediment linked to the production levels of seagrass detritus (Novak, 1989). Regarding the trophic availability in the sed- 
iments, in our study the stations with most silt are characterised by sand flats among seagrass beds. Nevertheless, the detritus derived from the Posidonia leaves is typically composed of structural materials not directly absorbed by detritivores indicating that food availability is the potential limiting factor for meiofaunal dynamics in the seagrass (Posidonia oceanica) sediments (Danovaro, 1996). Recent studies suggest that fine-sand habitats may promote larger patches of meiobenthic organisms than silty, muddy sediments (Sandulli and Pinckney, 1999), showing that benthic copepods and benthic microalgae exhibit patchiness at centimetre scales. This relates the distribution of meiobenthic copepods to a primary food resource, benthic microalgae. Among other factors decomposing animal tissue may be of primary importance regarding spatial distribution of meiobenthos (Olafsson, 1992).

The hydrodynamics of each area could influence the infaunal densities by producing differential responses of nematode assemblages to physical disturbance and organic enrichment. The findings that higher concentrations of meiobenthos are in the Port de Cabrera (stations 1 and 2) are in accordance with the characteristics of being a semi-enclosed bay with a low turnover and longer water residence time. Additionally, accumulation of wastes and organic matter are likely to be found during the summer period (presence of boats discharging in the bay and higher temperatures). In fact, as reported by Schratzberger and Warwick (1999) in treatments of physical and biological disturbance, the sand nematodes show most extreme changes as a result of organic enrichment, while mud nematodes showed the most intense response to treatments of physical disturbance. This hypothesis matches with our results of higher abundances in the sandy stations. Contrary to the high abundance attained in the Port de Cabrera, the adjacent bay of the island,
Ganduf, shows fairly low and somewhat aberrant values, especially at station 3 which has the highest silt fraction.

The results support the notion of a homogeneous benthos since the proportional representation of the various taxa comprising the fauna showed little variation between the stations. The average meiobenthic densities recorded at the Cabrera and Mallorca stations are consistent with those found in other shallow sublittoral sheltered bays characterised by fine and/or medium sandy sediments (Table 4). However, the values may be related with sediment characteristics (fine to medium sand), food availability and water and sediment temperature. The fact that sampling was carried out in summer, corresponding with maximum annual temperatures could be a possible source of bias in the densities observed. Generally, abundances are higher in summer, which seems to be a general characteristic of Mediterranean communities (Soyer, 1970; Nodot, 1978). Seasonal fluctuations in meiofauna densities are to be expected, therefore surveys throughout the year should have been carried out to test for seasonal patterns.

The nematode composition of the current study is in agreement with previous observations on sandy habitats (Heip et al., 1990). We observed a dominance of Desmodorids, Chromadorids, and Xyalids, while members of the Linhomoeids and Tripyloids were scarce. Furthermore, medium sand and/or less sorted sediments with a high gravel fraction are often characterised by the dominance of Chromadoridae and the subdominance of Desmodoridae (Tietjen, 1969, 1977, 1980; Ward, 1975). In well sorted, fine sandy sediments Desmodoridae and also Linhomoeidae, Comesomatidae, Xyalidae and Tripyloididae are dominant (Tietjen, 1969; Ward, 1975).

On a larger scale, sediment characteristics seem to determine the nematode assemblage structure.

TABLE 4. - Comparison of mean nematode and meiofaunal densities (individuals $10 \mathrm{~cm}^{-2}$ ) for shallow sublittoral areas of the Mediterranean.

\begin{tabular}{|c|c|c|c|}
\hline Authors & Habitat & Nemat. $\cdot 10 \mathrm{~cm}^{-2}$ & Meiofauna $\cdot 10 \mathrm{~cm}^{-2}$ \\
\hline Guille and Soyer, 1968 & mud & 79 & \\
\hline Soyer, 1971 & mud & 400 & \\
\hline Boucher, 1972 & mud & 3665 & 4500 \\
\hline de Bovée and Soyer, 1974 & silt & 4279 & \\
\hline Boucher, 1980 & sand & $1090-3432$ & \\
\hline de Bovée, 1987 & mud & & 3911 \\
\hline Deudero and Vincx, this study & Fine-medium sand & $424-2779$ & $1075-4137$ \\
\hline Soyer et al., 1987 & fine sand & & $45-250$ \\
\hline Soyer et al., 1988 & mud & & $1250-8000$ \\
\hline Palacín et al., 1991 & sand-silt & 61 & 7041 \\
\hline Palacín et al., 1992 & silt & $32-1003.2$ & $129.6-1628.8$ \\
\hline
\end{tabular}


Samples from the same station were more similar in terms of generic occurrence and population structure than samples from different stations in similar habitats according to the results from the multivariate analysis. This indicates that there are localised factors influencing the nematode populations on a small scale in each habitat-type. Therefore, the distribution and abundance of meiofauna should be considered carefully since many factors may influence the occurrence of organisms in sediments. In this sense, all the possible sources of spatial heterogeneity (food, predation, disturbance, biogenic structures, reproductive strategies and competition) can influence the structure of meiobenthic communities in this study.

Discrimination of disturbed and undisturbed sediments relying on the disparities in abundance and composition of the studied communities are difficult to assess, mainly due to the lack of information on parameters indicating distressed conditions, such as nutrient inputs, eutrophication processes, etc. However, the description of the meiobenthic populations of the area will provide a valuable data set for baseline studies of a unique area like the National Park of Cabrera. Moreover, the infaunal composition is typical of sandy sediments although with higher abundance values, probably determined by the Mediterranean summer maximum in meiobenthos density.

\section{ACKNOWLEDGEMENTS}

We thank ICONA (Instituto para la Conservación de la Naturaleza, Spain) for the facilities provided for sampling. This work was supported by a grant from the Ministerie van de Vlaamse Gemeenschap (Belgium) to the first author.

\section{REFERENCES}

Albertelli, G., A. Covazzi-Harriague, R. Danovaro, M. Fabiano, S. Fraschetti and A. Pusceddu. - 1999. Differential responses of bacteria, meiofauna and macrofauna in a shelf area (Ligurian Sea, NW Mediterranean): role of food availability. J. Sea Res., 42(1): 11-26.

Boucher, G. - 1972. Distribution quantitative et qualitative des nématodes d'une station de vase terrigène côtière de BanyulsSur-Mer. Cah. Biol. Mar., 13: 457-474.

Boucher, G. - 1980. Facteurs d'equilibre d'un peublement de nématodes des sables sublittoraux. Mém, Mus. National Histoire Nat. Série A. Tome 114.

Bougis, P. - 1946. Analyse quantitative de la microflore d'une vase marine à Banyuls-sur-Mer. C. R. Hebd. Séanc. Acad.Sci. Paris, 222: 1122 .

Danovaro, R., M. Fabiano, G. Albertelli and N. Dellacroce. - 1995a. Vertical Distribution of Meiobenthos in Bathyal Sediments of the Eastern Mediterranean Sea - Relationship With Labile Organic-Matter and Bacterial Biomasses. Mar. Ecol. Pubbl. Stn. Zool. Napoli, 16(2): 103-116.

Danovaro, R., M. Fabiano and M. Vincx. - 1995b. Meiofauna Response to the Agip-Abruzzo Oil-Spill in Subtidal Sediments of the Ligurian Sea. Mar. Pollut. Bull., 30(2): 133-145.

Danovaro, R. - 1996. Detritus- Bacteria-Meiofauna interactions in a seagrass bed (Posidonia oceanica) of the NW Mediterranean. Mar. Biol., 127: 1-13.

de Bovée, F. - 1987. Dynamique des peublements meiobenthiques sublittoraux. I. Les facteurs du milieu. Vie Milieu, 38 (1): $25-34$.

de Bovée, F. - 1988. Dynamique des peublements meiobenthiques sublittoraux. II. Le peublement des nématodes libres marins. Vie Milieu, 38 (2): 115-122.

de Bovée, F., L.D. Guidi and J. Soyer. - 1990. Quantitative Distribution of Deep-Sea Meiobenthos in the Northwestern Mediterranean (Gulf of Lions). Cont. Shelf Res., 10(9-11): 1123-1145.

Edgar, G.J., C. Shaw, G.F. Watson and L.S. Hammond. - 1994. Comparisons of Species Richness, Size-Structure and Production of Benthos in Vegetated and Unvegetated Habitats in Western- Port, Victoria. J. Exp. Mar. Biol. Ecol., 176(2): 201-226.

Gray, J.S. - 1971. The effects of pollution on sand meiofauna communities. Thalassia Jugosl., 7: 79-86.

Gray, J.S. and T.H. Pearson. - 1982. Objective selection of sensitive species indicative of pollution-induced change in benthic communities. I. Comparative methodology. Mar. Ecol. Prog. Ser., 9: 111-119.

Guidiguilvard, L.D. and R. Buscail. - 1995. Seasonal Survey of Metazoan Meiofauna and Surface Sediment Organics in a NonTidal Turbulent Sublittoral Prodelta (Northwestern Mediterranean). Cont. Shelf Res., 15(6): 633-653.

Heip, C., M. Vincx and G. Vranken. - 1985. The ecology of marine nematodes. Oceanogr. Mar. Biol. Ann. Rev., 23: 399-489.

Heip, C., R. Huys, M. Vincx, A. Vanreusel, A.N. Smol, R. Herman and P.M.J. Herman. - 1990. Composition, distribution, biomass and production of North Sea meiofauna. Neth. J. Sea Res., 26 (2-4): 333-342.

Lardicci, C., F. Rossi and F. Maltagliati. - 1999. Detection of thermal pollution: Variability of benthic communities at two different spatial scales in an area influenced by a coastal power station. Mar. Pollut. Bull., 38(4): 296-303.

McIntyre, A.D. and R.M. Warwick. - 1984. Meiofauna techniques. N.A. Holme and A.D. McIntyre (eds.), Methods for the study of marine benthos, Blackwell Scientific Publications, Oxford.

Ndaro, S.G.M. and E. Olafsson. - 1999. Soft-bottom fauna with emphasis on nematode assemblage structure in a tropical intertidal lagoon in Zanzibar, eastern Africa: I. Spatial variability. Hydrobiologia, 405: 133-148.

Nodot, C. - 1978. Cycles biologiques de quelques espèces de copépodes harpacticoides psammiques. Tethys, 8: 241-48.

Novak, R. - 1989. Ecology of Nematodes in the Mediterranean Seagrass Posidonia oceanica (L) Delile. 1. General Part and Faunistics of the Nematode Community. Mar. Ecol. Pubbl. Stn. Zool. Napoli, 10(4): 335-363.

Olafsson, E. - 1992. Small-Scale Spatial-Distribution of Marine Meiobenthos - the Effects of Decaying Macrofauna. Oecologia, 90(1): 37-42.

Palacín, C., D. Martín and J.M. Gili. - 1991. Features of spatial distribution of benthic infauna in a Mediterranean shallow-water bay. Mar. Biol., 110: 315-321.

Palacín, C., J.M. Gili and D. Martin. - 1992. Evidence For Coincidence of Meiofauna Spatial Heterogeneity With Eutrophication Processes in a Shallow-Water Mediterranean Bay. Estuar. Coast. Shelf Sci., 35(1): 1-16.

Papadopoulou, K.N., I. Karakassisand and A. Otegui. - 1998. Harbour meiofaunal communities and organic enrichment effects. Fresenius Environ. Bull., 7(1-2): 34-41.

Platt, H.M. and R.M. Warwick. - 1983a. Free-living marine nematodes. Part I. British enoplids. Synopses of the British fauna (new series), No. 28. Cambridge University Press, Cambridge.

Platt, H.M. and R.M. Warwick. - 1983b. Free-living marine nematodes. Part II. British chromadorids. Synopses of the British fauna (new series), No. 38. E J Brill/Dr W Backhuys, Leiden.

Sandulli, R. and J. Pinckney. - 1999. Patch sizes and spatial patterns of meiobenthic copepods and benthic microalgae in sandy 
sediments: a microscale approach. J. Sea Res., 41(3): 179-187. Schewe, I. and T. Soltwedel. - 1999. Deep-sea meiobenthos of the central Arctic Ocean: distribution patterns and size-structure under extreme oligotrophic conditions. Vie Milieu, 49(2-3): 79-92.

Schratzberger, M. and R.M. Warwick. - 1998. Effects of the intensity and frequency of organic enrichment on two estuarine nematode communities. Mar. Ecol. Progr. Ser., 164: 83-94.

Schratzberger, M. and R.M. Warwick. - 1999. Differential effects of various types of disturbances on the structure of nematode assemblages: an experimental approach. Mar. Ecol. Progr.Ser., 181: 227-236.

Smol, N., K.A. Willems, J.C.R. Govaere and A.J.J. Sandee. - 1994 Composition, Distribution and Biomass of Meiobenthos in the Oosterschelde Estuary (Sw Netherlands). Hydrobiologia, 283: 197-217.

Soetaert, K. and C. Heip. - 1995. Nematode Assemblages of DeepSea and Shelf Break Sites in the North-Atlantic and Mediterranean-Sea. Mar. Ecol. Progr. Ser., 125(1-3): 171-183.

Soetaert, K., C. Heip and M. Vincx. - 1991. The Meiobenthos Along a Mediterranean Deep-Sea Transect Off Calvi (Corsica) and in an Adjacent Canyon. Mar. Ecol. Pubbl. Stn. Zool. Napoli, 12(3): 227-242.

Soetaert, K., M. Vincx and C. Heip. - 1995. Nematode community structure along a Mediterranean shelf-slope gradient. Mar. Ecol. Pubbl. Stn. Zool. Napoli, 16(3): 189-206.

Soyer, J. - 1970. Bionomie Benthique du plateau continental de la côte catalane française. III.- Les peuplements de copépodes harpacticoides (Crustacea). Vie Milieu, 21: 337.

Soyer, J. - 1971. Bionomie Benthique du plateau continental de la côte catalane française. V- Densités et biomasses du méiobenthos. Vie Milieu, Vol. XXII, fasc. 2, sér. B: 351-424.

Soyer, J., F. de Bovée and L. Guidi. - 1987. Repartition quantitative du meiobenthos dans le bassin ocidental mediterraneen. Coll. Intern. d'Océanol. Perpignan, C.I.E.S.M., Perpignan.

Tietjen, J.H. - 1969. The ecology of shallow water meiofauna in two New England estuaries. Oecologia, 2: 251.

Tietjen, J.H. - 1977. Population distribution and structure of the free-living Nematodes of Long Islands. Mar. Biol., 43: 123.

Tietjen, J.H. - 1980. Population structure and species composition of the free-living nematodes inhabiting sands of the New York Bight Apex. Estuar. Coast. Shelf Sci., 10: 61-73.

Villoramoreno, S., R. Capaccioniazzati and A.M. Garciacarrascosa. - 1991. Meiobenthos of sandy beaches from the Gulf-of-Valencia (Western Mediterranean) - Ecology of interstitial polychaetes. Bull. Mar. Sci., 48(2): 376-385.

Ward, A.R. - 1975. Studies on the sublittoral free-living nematodes of Liverpool Bay. II. Influence of sediment composition on the distribution of marine nematodes. Mar. Biol., 30: 217-225.

Woodin, S.A. - 1978. Refuges, disturbance and community structure: a marine soft-bottom example. Ecology, 59(2): 274-184.

Scient. ed.: C. Heip 